\title{
Pemanfaatan Batu Sungai Sa'dan Toraja Utara Sebagai Campuran Stone Matrix Asphalt Halus
}

\author{
Riki Adi Jansen ${ }^{\star 1}$, Nur Ali², Rais Rachman ${ }^{\star 3}$ \\ ${ }^{* 1}$ Mahasiswa Teknik Sipil, Universitas Kristen Indonesia Paulus, Makassar, Indonesia \\ jansenrikiadi@gmail.com \\ *2,3 Dosen Teknik Sipil, Unversitas Kristen Indonesia Paulus, Makassar, Indonesia \\ nuralimti@gmail.com dan rais.rachman@gmail.com
}

\begin{abstract}
ABSTRAK
Sungai Sa'dan di Pangli Kecamatan Sesean, adalah salah satu Sungai di Kabupaten Toraja Utara yang memiliki sumber batu yang dapat digunakan sebagai bahan perkerasan jalan. Namun, material belum pernah diuji secara labotarium sebagai salah satu persyaratan untuk dapat digunakan sebagai material untuk perkerasan jalan utamanya campuran Stone Matrix Asphalt (SMA). Tujuan penelitian ini untuk mengetahui pemanfaatan batu sungai Sa'dan sebagai campuran Stone Matrix Asphalt Halus menggunakan variasi kadar aspal 6.00\%, 6.25\%, 6.50\%, 6.75\% dan 7.00\%. Spesifikasi yang digunakan adalah Spsifikasi Bina Marga 2018 Divisi 6 Revis1 1. Berdasarkan hasil pengujian Batu dari sungai Sa'dan kelurahan Pangli Kecamatan Sesean Kabupaten Toraja Utara dapat dimanfaatkan sebagai bahan untuk campuran Stone Matrix Asphalt (SMA) halus. Kadar aspal yang dapat digunakan pada pencampuran ini, dapat menggunakan kadar aspal antara $6 \%$ sampai dengan $7 \%$ namun untuk mendapatkan campuran yang lebih kedap air dapat menggunakan kadar aspal $7 \%$. Hasil uji marshall immersion dengan menggunakan kadar aspal 7\% adalah 96,30\%, hal ini menunjukkan campuran tersebut akan tahan terhadap perendaman selama 24 jam.
\end{abstract}

Kata kunci : Pemanfaatan, SMA, Marshall Test, Spesifikasi

\begin{abstract}
The Sa'dan River in Pangli, Sesean District, is one of the rivers in North Toraja Regency which has a source of stone which can be used as road pavement material. However, the material has never been tested labotarium as one of the requirements to be used as a material for pavement especially the mixture of Stone Matrix Asphalt (SMA). The purpose of this study was to determine the use of the Sa'dan river stone as a mixture of Fine Asphalt Stone Matrix using variations of asphalt content of $6.00 \%, 6.25 \%, 6.50 \%, 6.75 \%$ and $7.00 \%$. The specifications used are the Specifications of Bina Marga 2018 Division 6 Revis1 1. Based on the results of testing stones from the Sa'dan river, Pangli sub-district, Sesean District, North Toraja Regency, it can be used as a material for a fine mixture of Stone Matrix Asphalt (SMA). The asphalt content that can be used in this mixing, can use asphalt levels between $6 \%$ to $7 \%$ but to get a more water-resistant mixture can use an asphalt content of $7 \%$. The results of the Marshall immersion test using $7 \%$ asphalt content was $96.30 \%$, this indicates that the mixture will withstand immersion for 24 hours.
\end{abstract}

Keywords: Utilization, SMA, Marshall Test, Specifications

\section{PENDAHULUAN}

Pemanfaatan material local atau setempat sangat menunjang jalannya pembangunan pada wilayah setempat. Salah satu wilayah di Provinsi Sulawesi Selatan yang memiliki material batu yaitu Kabupaten Toraja Utara. Sungai Sa'dan di Pangli Kecamatan Sesean, adalah salah satu Sungai di Kabupaten Toraja Utara yang memiliki sumber batu yang dapat digunakan sebagai bahan perkerasan jalan. Namun, material belum pernah diuji secara labotarium sebagai salah satu persyaratan untuk dapat digunakan sebagai material untuk perkerasan jalan utamanya campuran Stone Matrix Asphalt (SMA).

Salah satu campuran aspal yang mempunyai kadar aspal relatif tinggi dan dapat memenuhi sifat rongga yang terisi aspal sehingga tahan terhadap oksida adalah SMA. SMA dapat diterapkan pada iklim tropis dengan cuaca panas dan hujan yang berganti-ganti dengan volume lalulintas yang tinggi, seperti pada Kabupaten Toraja Utara. Stone Matrix Asphalt (SMA) terdiriri atas SMA kasar, SMA halus 
dan SMA tipis. Dalam penelitian ini menggunakan SMA Halus.

Penggunaan material untuk suatu perkerasan jalan dapat di tinjau dari karakrakteristik dari material tersebut dalam suatu pengujian di laboratorium [1] [2]. Selain karakteristik material, karakteristik campuran juga menunjang untuk suatu pemanfaatan yang dapat di analisis melalui analisis VIM, VMA, VFB, Stabilitas dan pelelhan (flow) campuran tersebut [3]-[4]. Untuk mengetahui ketahanan suatu campuran tahan terhadap genangan air diperlukan suatu analisis terhadap stabilitas marshall konvensional dengan stabilitas marshall Immersion [5].

Telah banyak penelitian terhadap penggunaan material local antara lain Pemanfaatan Agregat Sungai Lamasi Kabupaten Luwu Sebagai Campuran Lapisan Aspal Beton AC-WC [6]. Pengujian Karakteristik Campuran HRS-WC Menggunakan Batu Sungai Makawa Kecamatan Walenrang Utara [7]. Penggunaan Agregat Sungai Batu Tiakka' dalam Campuran AC-BC [8].

Beberapa peneliti sebelumnya yang meneliti penggunaan SMA sebagai bahan perkerasan jalan antara lain Alternatif Penggunaan Serat Eceng Gondok pada Campuran Stone Matrix Asphalt Gradasi Halus Meningkatkan Stabilitas Campuran Aspal Panas [9]. Analisis Kekuatan Tarik Material Campuran Sma (Split Mastic Asphalt) Grading 0/11 Menggunakan Sistem Pengujian Indirect Tensile Strength [10]. Analisis Tensile Strength Bending Cantabro dan Permeabilitas pada Split Mastic Asphalt (SMA) dengan Bahan Tambah High Density Polyetylene (HDPE) [11]. Pengembangan Campuran Split Mastic Asphalt (SMA) Menggunakan Bahan Reclaimed Asphalt Pavement (RAP) dengan Serat Selulosa Alami Dedak Padi [12].

Tujuan penelitian ini untuk mengetahui pemanfaatan batu sungai Sa'dan Kabupaten Toraja Utara sebagai campuran Stone Matrix Asphalt Halus menggunakan variasi kadar aspal $6.00 \%$, $6.25 \%, 6.50 \%, 6.75 \%$ dan $7.00 \%$. Spesifikasi yang digunakan adalah Spsifikasi Bina Marga 2018 Divisi6 Reviss 1 [13].

\section{METODE PENELITIAN}

\section{Lokasi pengambilan material.}

Agregat diperoleh dari sungai Sa'dan Kelurahan Pangli Kabupaten Toraja Utara dalam bentuk bentuk utuh dengan ukuran $\pm 20 \mathrm{~cm}$ dengan pengambilan secara manual dengan jumlah sebanyak $25 \mathrm{~kg}$. Selanjutnya batu sungai tersebut di pecahkan secara manual pada laboratorium Jalan dan Aspal Universitas Kristen Indonesia Paulus. Lokasi pengambilan material dapat dilihat pada gambar 1 .

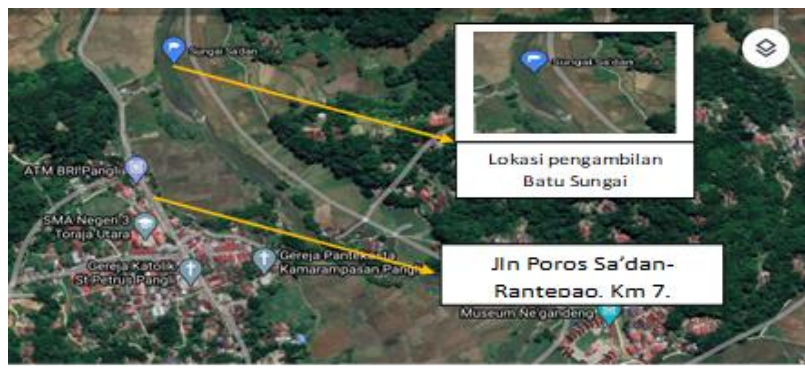

\section{Gambar 1. Lokasi Material}

\section{Pemeriksaan karakteristik material}

Pemeriksaan karakteristik material berupa, karakteristik agregat kasar, agregat halus, filler serta aspal. pengujian terhadap agrgat kasar dilakukan terhadap analisa saringan, abrasi, kelekatan agregat terhadap aspal, partikel pipih dan lonjong, dan material lolos ayakan No.200. Pengujian agregat halus berupa nilai setara pasir, gumpalan lempung dan butir-butir mudah pecah dalam agregat. Pengujian karakteristik aspal berupa Penetrasi pada $25^{\circ} \mathrm{C}$, Viskositas Kinematis $135^{\circ} \mathrm{C}$, Titik Lembek $\left({ }^{\circ} \mathrm{C}\right)$, Daktilitas pada $25^{\circ} \mathrm{C}$, $(\mathrm{cm})$, Titik Nyala $\left({ }^{\circ} \mathrm{C}\right)$, Berat Jenis, Berat yang Hilang (\%), Daktilitas pada $25^{\circ} \mathrm{C}(\mathrm{cm})$. Semua pengujian berdasarkan SNI yg di tentukan dalam spesifikasi Bina Marga 2018.

\section{Rancangan campuran}

Proses perancangan campuran pada penelitian ini menggunakan metode pengujian Marshall (ASTM D6927-06). Komposisi rancangan campuran didasarkan pada gradasi ideal antara batas atas dan batas bawah seperti terlihat pada tabel 1 .

Tabel 1. Rancangan gradasi campuran

\begin{tabular}{ccccc}
\hline \multicolumn{2}{c}{ Ukuran saringan } & \multicolumn{3}{c}{ Lolos Saringan } \\
\hline Inchi & Mm & Spesifikasi (\%) & $\begin{array}{c}\text { Gradasi } \\
\text { Campuran (\%) }\end{array}$ \\
\hline 1" & 25 & \multicolumn{2}{c}{100} \\
$3 / 4 "$ & 19 & 90 & -100 & 95
\end{tabular}




\begin{tabular}{cccccc}
$1 / 2 "$ & 12.5 & 50 & - & 88 & 69 \\
$3 / 8 ”$ & 9.5 & 25 & - & 60 & 42,5 \\
4 & 4.75 & 20 & - & 28 & 24 \\
8 & 2.36 & 16 & - & 24 & 20 \\
200 & 0.075 & 8 & - & 11 & 9,5 \\
\hline
\end{tabular}

\section{Komposisi campuran}

Dari hasil rancangan didapatkan komposisi agregat seperti pada tabel 2 .

Tabel 2. Komposisi campuran

\begin{tabular}{cccccc}
\hline \multirow{5}{*}{$\begin{array}{c}\text { Kadar } \\
\text { aspal (\%) }\end{array}$} & $\mathbf{6 , 0 0 \%}$ & $\mathbf{6 , 2 5 \%}$ & $\mathbf{6 , 5 0 \%}$ & $\mathbf{6 , 7 5 \%}$ & $\mathbf{7 , 0 0 \%}$ \\
\cline { 2 - 6 } & $\mathbf{6 , 5}$ & & & & \\
\hline $\begin{array}{c}\text { Berat } \\
\text { agregat } \\
\text { (gram) }\end{array}$ & 1128 & 1125 & 1122 & 1119 & 1116 \\
\hline $\begin{array}{c}\text { Berat aspal } \\
\text { (gram) }\end{array}$ & 72 & 75 & 78 & 81 & 84 \\
\hline $\begin{array}{c}\text { Berat } \\
\text { campuran } \\
\text { (gram) }\end{array}$ & 1200 & 1200 & 1200 & 1200 & 1200 \\
\hline
\end{tabular}

Dari komposisi campuran dibuatkan benda uji dengan jumlah seperti pada tabel 3 .

Tabel 3. Jumlah benda uji

\begin{tabular}{cccc}
\hline No. & $\begin{array}{c}\text { kadar } \\
\text { Aspal } \\
(\%)\end{array}$ & $\begin{array}{c}\text { Pengujian } \\
\text { Marshall } \\
\text { Konvensional }\end{array}$ & $\begin{array}{c}\text { Pengujian } \\
\text { Marshall } \\
\text { Immersion }\end{array}$ \\
\hline 1 & 6 & 3 & \\
2 & 6,25 & 3 & \\
3 & 6,5 & 3 & 3 \\
4 & 6,75 & 3 & \\
5 & 7 & 3 & 3 \\
\hline \multicolumn{5}{r}{ Total } & 15 & \\
\hline
\end{tabular}

\section{Marshal Konvensional}

Pengujian marsahall merupakan pengujian tekan terhadap benda uji untuk mengukur nilai stabilitas dan flow. Tahapan kinerja yaitu penetuan berat benda uji, pengujian stabilitas, pengujian pelelehan (flow) [14], Perhitungan Marshall Quotient adalah perbandingan antara nilai stabilitas dan kelelehan, Perhitungan berbagai jenis volume berpori dalam aspal beton padat (VMA dan VFA), Perhitungan tebal selimut atau film asphalt [13] [15].

6. Kadar aspal optimum
Dari hasil pengujian Marshall Konvensional dilanjutkan dengan kadar aspal optimum. Data-data dari pengujian Marshall Konsvensional dikelolah pada tabel data Hot Mix Desain metode Marshall.

Dari hasil tabulasi dapat dilihat nilai stabilitas, flow, VIM, VMA yang memenuhi syarat spesifikasi yang digunakan berdasarkan persyaratan campuran Stone Matrix Asphalt (SMA). Dasar pemilihan kadar aspal optimum didasarkan pada campuran yang memenuhi kriteria/karakteristik campuran dimana memiliki nilai Voite In Mix (VIM) terkecil. Karena jika campuran dengan Void In Mix (VIM) yang mempunyai rongga lebih kecil akan tahan terhadap perendaman.

\section{Marshall Immersion}

Marshal Immersion didapatkan dari hasil pengujian stabilitas dari benda uji yang sebelumnya direndam selama 24 jam dengan suhu $\pm 60^{\circ} \mathrm{C}$ sebelum pembebanan diberikan. Dari hasil pengujian ini didapatkan stabilitas Marshall sisa (SMS) dengan perentase dari hasil perbandingan antara stabilitas marshall immersion dengan stabilitas marshall konvensional. Pada pengujian ini hanya menggunakan kadar aspal optimum dan dibuatkan sampel sebanyak 3 buah.

\section{ANALISIS dan PEMBAHASAN}

\section{Karakteristik Material \\ a. Aggregate}

Hasil uji aggregate material kasar dan halus menunjukkan uji keausan di Los Angeles bahwa nilai ketahanan aus agregat kasar dari kelompok $A$ sebesar 3,4\%, kelompok B sebesar 3,64\%, kelompok C sebesar 3,28\%, dan kelompok D sebesar 3,92\%.

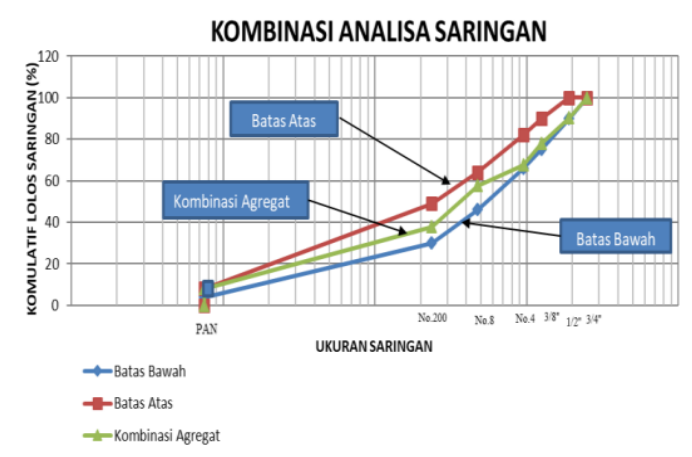

Gambar 2. Hasil pengujian Analisa saringan 
Hasil semua uji diatas, masing-masing skor yang di dapat telah melampaui syarat ketentuan, sehingga material dapat dipakai dalam campuran. Hasil dari penelitian penggunaan dua sampel untuk menguji densitas dan absorpsi agregat kasar, densitas bulk 2.55, densitas SSD 2.60, densitas semu 2,67, dan daya serap air $1,75 \%$.Nilai pengujian densitas dan absorpsi agregat halus didapatkan bulk density 2,62, berat jenis SSD 2,64,

Berdasarkan Gambar 2, hasil analisis saringan ditunjukan dalam bentuk grafik agregat dan spesifikasinya. Nilai agregat mendekati batas atas, yang menunjukkan bahwa agregat dari Sungai Sadan di Kabupaten Toraja Utara melampaui standard spekifik.

Berdasarkan hasil uji, lolos saringan No. 200, terhitung 2,80\%, sehingga memenuhi persyaratan 2018 "Spesifikasi Teknis Umum Jalan Raya", dan tidak lebih dari $10 \%$. Terlihat tidak adanya lanau dan lanau di saluran Sungai Sadan di Kabupaten Toraha Utara.

Dari hasil penggunaan 2 (dua) sampel untuk menguji nilai ekuivalen sludge diperoleh rata-rata nilai ekuivalen pasir ialah 9.7,40\%. Kadar lumpurnya $2,6 \%$.

Dari hasil uji agregat partikel datar dan material kasar elips didapatkan nilai partikel rata masingmasing sebesar 3,81\%, 3,95\%, dan 2,71\%. Partikel elips masing-masing adalah $3,86 \%, 3,97 \%$, dan $2,51 \%$. Kedua nilai ini sejalan dengan "Aturan Umum untuk Jalan Raya" 2018, dan jumlah maksimum tidak melebihi 10\%.

Hal tersebut dapat dilihat dari hasil uji adhesi total pada aspal. Aspal hanya divisualisasikan dan tidak melalui proses perhitungan. Nilai adhesi ditentukan oleh luas permukaan (kurang dari 95\% atau lebih besar dari 95\%) sampel yang dilapisi aspal. Dari hasil pengamatan tersebut terlihat aspal melekat baik pada agregat

Berat Jenis Filler, standar spesifikasi tidak menentukan nilai, dimana bahan yang digunakan pada campuran adalah Cement Portland.

\section{b. Aspal}

Aspal yang dipakai pada penelitian ini untuk membuat campuran aspal berbahan dasar batu adalah aspal minyak penetrasi 60/70.
Berdasarkan hasil uji penetrasi, diperoleh hasil uji penetrasi $67,7 \mathrm{~mm}$. Telah memenuhi spek minimum yang di tetapkan. Nilai rata-rata yang diperoleh dari hasil pengujian titik lembek adalah $50,2^{\circ} \mathrm{C}$. Hasil tersebut sudah termasuk dalam persyaratan

Nilai rata-rata yang diperoleh dari hasil pengujian titik nyala adalah 2900C. Dari percobaan yang dilakukan di didapatkan hasil penurunan berat rata - rata $0,4,34 \%$. Hasil ini sesuai spesifikasiJalan Raya 2018, yaitu maksimal $0,8 \%$.

Berdasarkan hasl uji penerasi T.F.O.T diperoleh nilai rataan $84,7 \%$. syarat yang disinkan yaitu minimum $5,4 \%$ dari tingkat penerasi asli.

Berdasarkan hasil uji keuletan diperoleh nilai rataan $150 \mathrm{~cm}$. Hasil tersebut telah tercantum dalam persyaratan standar spesifikasi. Berat jenis diperoleh nilai rataan $1, .015 \mathrm{gr} / \mathrm{cc}$.nilai ini telah memenuhi standar.

\section{Marshall Konvensional}

Benda uji dibentuk dengan kenaikan kadar aspal S.M.A yaitu $6 \%-7 \%$, dengan kenaikan $0,25 \%$ tiap sampel.Hasil hitunga massa jenis volume dan berat jenis efektif dapat diperhatikan pada Tabel 4 berikut ini:

Tabel 4. Berat jenis

\begin{tabular}{lccccc}
\hline Kadar Aspal \% & $\begin{array}{c}6,00 \\
\%\end{array}$ & $\begin{array}{c}6.25 \\
\%\end{array}$ & $\begin{array}{c}6,50 \\
\%\end{array}$ & $\begin{array}{c}6,75 \\
\%\end{array}$ & $\begin{array}{c}7,00 \\
\%\end{array}$ \\
\hline $\begin{array}{l}\text { Bulk Spesific } \\
\text { Gravity Agrerat } \\
\text { Effective Spesific } \\
\text { Gravity Agrerat }\end{array}$ & 2.77 & 2.78 & 2.78 & 2.79 & 2.80 \\
\hline
\end{tabular}

Tabel 5 mencantumkan hasil pengujian karakteristik Marshall konvensional, termasuk stabilitas, VIM (rongga dalam pencampuran), aliran, VMA (rongga dalam agregat mineral).

Tabel 5. karakteristik Marshall konvensional

\begin{tabular}{ccccc}
\hline $\begin{array}{c}\text { Persyara } \\
\text { tan }\end{array}$ & $\begin{array}{c}\text { Min 4-5 } \\
(\%)\end{array}$ & $\begin{array}{c}\text { Min 600 } \\
(\mathrm{kg})\end{array}$ & $\begin{array}{c}\text { Min 2-4,5 } \\
(\mathrm{mm})\end{array}$ & $\begin{array}{c}\text { Min 17 } \\
(\%)\end{array}$ \\
\hline $\begin{array}{c}\text { Kadar } \\
\text { Aspal } \\
(\%)\end{array}$ & VIM & Stabilitas & Flow & VMA \\
\hline 6 & 4.93 & 911.02 & 3.52 & 17.72 \\
6,25 & 4.72 & 949.14 & 2.95 & 18.12 \\
6,5 & 4.50 & 1040.63 & 2.35 & 18.51 \\
6,75 & 4.36 & 968.20 & 2.60 & 18.97 \\
7 & 4.10 & 926.27 & 3.40 & 19.33 \\
\hline
\end{tabular}




\section{a. VIM ( Void in Mix)}

Nilai hasil pengujian VIM pada Tabel 5 di visualisasikan dan dapat dilihat pada gambar 3 .

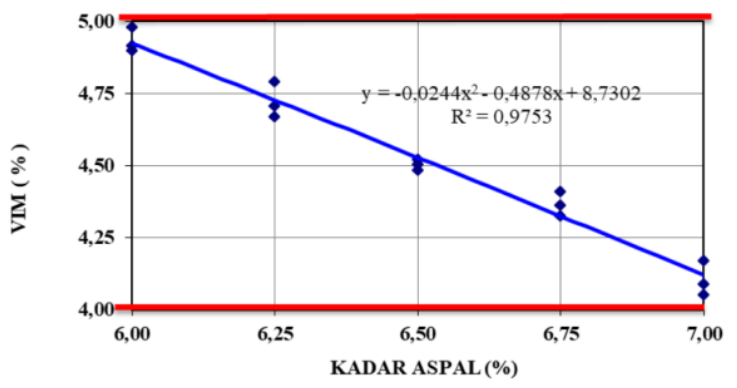

Gambar 3. Hubungan antara VIM dan kandungan aspal

Dari gambar 3 terlihat nilai VIM dengan kadar aspal $6,00 \%$ sampai dengan kadar aspal 7,00\% cenderung mengalami penurunan. dari gambar tersebut dapat diketahui bahwa semakin banyak kadar aspal yang digunakan akan menurukan nilai VIM begitupun sebaliknya. Dari gambar 3 didapatkan persamaan garis $\mathrm{y}=-0,0244 \mathrm{x} 2$ $0,4878 x+8,7302$, dimana persamaan ini menunjukan kenaikan 0,25\% kadar aspal, maka VIM semakin menurun. Dari persamaan ini didapatkan nilai VIM minimum 4\% pada kadar aspal 7,14\%, sedangkan VIM mencapai batas maksimum yaitu $5 \%$ pada kadar aspal $5.90 \%$

\section{b. Stabilitas}

Nilai stabilitas pada tabel 5 menunjukkan nilai antara $911,02 \mathrm{~kg}$ dan $926,27 \mathrm{~kg}$. Nilai ini memenuhi persyaratan. Berdasarkan nilai ini, digambarkan hubungan antara nilai stabilitas dan kadar aspal, seperti yang ditunjukkan pada Gambar4.

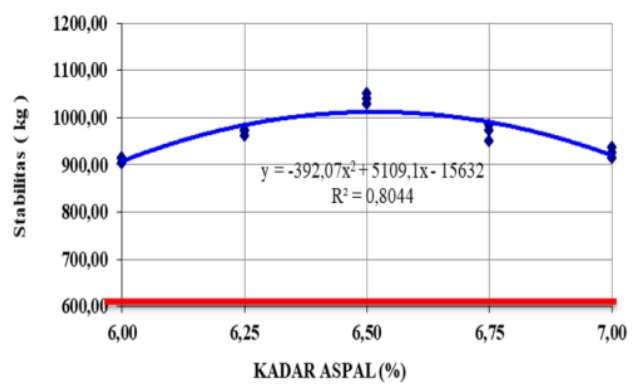

\section{Gambar4. Hubungan antara stabilitas dan kandungan aspal}

Penggunaan kadar aspal 6,00\% sampai dengan $7,00 \%$ diperoleh nilai Stabilitas antara $911.02 \mathrm{~kg}$ sampai dengan $926.27 \mathrm{~kg}$. Dari gambar 4 terlihat nilai stabilitas mengalami kenaikan dan penurunan stabilitas terjadi kadar aspal $6.50 \%$ sampai dengan kadar aspal 7,00\%. Berdasarkan gambar 4 dapat diketahui bahwa penggunaan kadar aspal yang sedikit dalam campuran akan menghasilkan selimut aspal yang tipis pada permukaan agregat yang mengakibatkan ikatan antar agregat (Interlocking) menjadi lemah sehingga stabilitas campuran kecil, tetapi jika aspal bertambah lagi maka selimut aspal menjadi tebal sehingga ikatan antar agregat menjadi kuat atau stabil. Kemudian jika aspal bertambah banyak lagi maka selimut aspal menjadi semakin tebal yang akan mengakibatkan ikatan antar agregat atau stabilitas campuran kembali menurun.

Dari gambar 4 didapatkan persamaan garis $\mathrm{y}=$ $392,07 x 2+5109,1 x-15632$. Dari gmabar ini diperoleh fenomena bahwa setiap kenaikan kadar aspal, nilai stabilitas bertambah sampai pada kadar aspal 6,52\%, dan jika kadar aspal bertambah maka stabilitas akan terjadi penurunan. Hasil perhitungan persamaan Regresi menunjukkan bahwa Stabilitas maksimum berada pada kadar aspal 6,52\% dengan nilai stabilitas sebesar $1012.29 \mathrm{~kg}$.

\section{c. Flow}

Gambar 6 menjelaskan bahwa penggunakan kadar aspal antara $6,00 \%$ sampai dengan 7,00\% diperoleh nilai Flow antara $3.52 \mathrm{~mm}$ sampai dengan $3,40 \mathrm{~mm}$. Dimana pada kadar aspal $6,00 \%$ sampai dengan $6,50 \%$ mengalami penurunan nilai flow sedangkan kadar aspal $6,75 \%$ sampai dengan $7,00 \%$ terjadi kenaikan nilai flow. Dari gambar ini dapat diketahui bahwa, apabila penggunaan aspal pada campuran jumlahnya kecil maka ikatan antar agregat akan berkurang dan akan terjadi pelelehan yang besar. Tetapi jika penggunaan aspal bertambah maka ikatan antar agregat yang terjadi dalam campuran akan menjadi lebih kuat dan pelelehan pada campuran akan menurun, sedangkan jika penggunaan aspal yang lebih banyak maka selimut aspal menjadi lebih tebal yang mengakibatkan kekuatan campuran akan berkurang dan pelelehan bertambah besar, yang berakibat kekuatan campuran/stabilitas akan berbanding terbalik dengan pelelehan campuran/Flow.

Berdasarkan Gambar 6 didapatkan persamaan garis $y=4,0952 x 2-53,471 x+176,99$, dimana persamaan ini menunjukan bahwa setiap kenaikan 
0,25\% kadar aspal, maka nila flow terjadi penurunan sampai dengan kadar aspal 6,53\%, sedangkan apabila kadar aspal bertambah secara terus menerus maka nilai flow juga akan bertambah. Hasil perhitungan persamaan regresi menunjukkan bahwa nilai Flow minimum berada pada kadar aspal $6,53 \%$ dengan nilai $2,447 \% \mathrm{~mm}$.

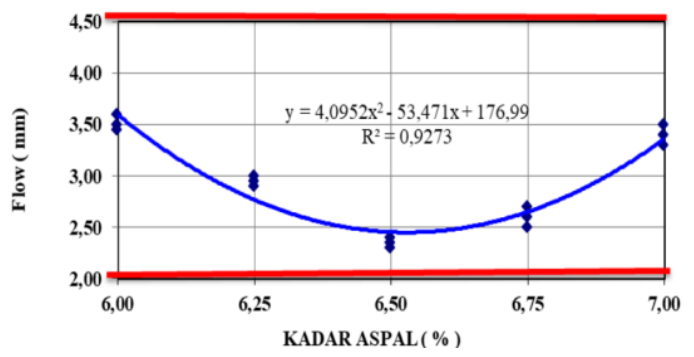

Gambar 6. Hubungan antara flow dengan kadar aspal

\section{d. VMA (Void in Mineral Aggregate)}

Hasil analisis seperti pada tabel 5 divisualidasikan seperti terlihat pada gambar 7 .

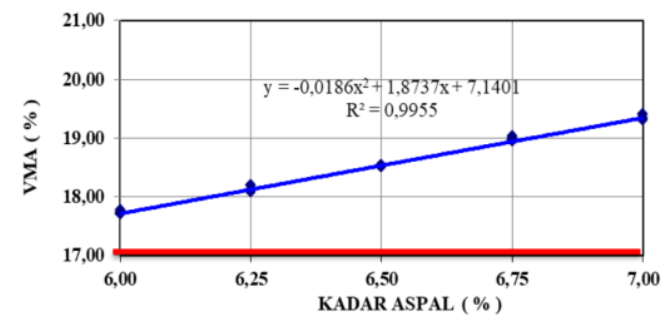

\section{Gambar 7. Hubungan antara V.M.A dengan kadar aspal}

Dari gambar 7 menunjukkan penggunaan kadar aspal $6,00 \%$ sampai dengan kadar aspal 7,00\% diperoleh nilai VMA antara $17,72 \%$ sampai dengan $19,33 \%$ Dari gambar ini, terlihat dengan kadar aspal $6,00 \%$ sampai dengan $7,00 \%$ nilai VMA terus mengalami peningkatan. $\mathrm{Hal}$ ini dipengaruhi oleh jumlah aspal yang digunakan, dimana fungsi aspal selain menyelimuti juga berfungsi untuk mengisi rongga diantara agregat dan dalam partikel agregat. Dari Gambar 7 dapat diketahui bahwa semakin banyak jumlah aspal yang di gunakan maka rongga dalam agregat yang terisi aspal semakin besar sehingga nilai VMA akan meningkat. Hal ini dipengaruhi oleh penggunaan aspal yang banyak dimana saat pencampuran dan pemadatan, aspal akan menyelimuti agregat, mengisi rongga diantara agregat dan mengisi rongga dalam agregat.
Berdasarkan Gambar 7 didapatkan persamaan garis $y=-0,0186 x 2+1,8737 x+7,1401$. Dari persamaan ini, menunjukan setiap kenaikan $0,25 \%$ kadar aspal, maka VMA semakin meningkat. Hasil perhitungan persamaan Regresi menunjukkan bahwa VMA mencapai batas minimum yaitu $17 \%$ pada kadar aspal $5.57 \%$.

\section{Penentuan K.A.O}

Berdasarkan hasil analisis karakteristik campuran dengan variasi kadar aspal 6,00\% 6,25\% 6,50\% $6.75 \%$ dan $7,00 \%$ semua memenuhi persyaratan spesifikasi yang digunakan. Hasil analisis dapat dilihat pada gambar 8 .

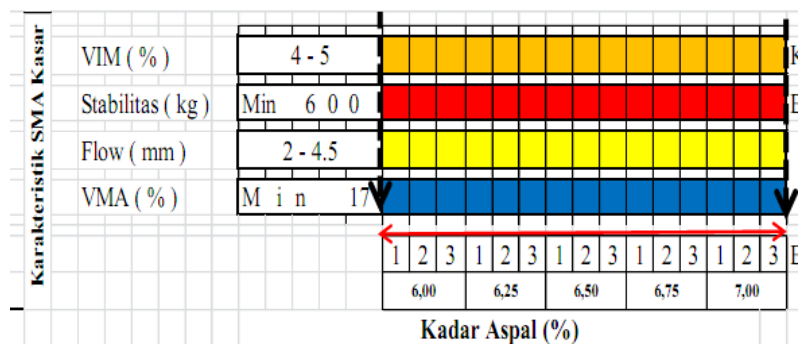

\section{Gambar 8. Diagram Analisis Kadar Aspal Optimum}

Karena nilai karakteristik campuran semua memenuhi persyaratan, maka untuk menentukan nilai kadar aspal optimum yang akan digunakan pada pengujian stabilitas dari marshall immersion mengambil nilai VIM paling kecil yaitu pada kadar aspal $7,00 \%$. Ini dikarenakan lapisan permukaan harus kedap air sehingga nilai rongga dalam campuran harus lebih kecil sehingga menjadikan kedap air.

\section{Stabilitas Marshall Sisa}

Hasil pengujian stabilitas marshall immersion dengan menggunakan kadar aspal $7 \%$ dapat dilihat pada tabel 6 .

Tabel 6. Hasil pengujian indeks kekuatan sisa

\begin{tabular}{|c|c|c|c|}
\hline \multirow{2}{*}{$\begin{array}{c}\text { Kadar Aspal } \\
(\%)\end{array}$} & \multicolumn{2}{|c|}{ Stabilitas } & \multirow{2}{*}{$\begin{array}{l}\text { Stabilitas } \\
\text { Marshall } \\
\text { Sisa (\%) }\end{array}$} \\
\hline & Konvensional & Immertion & \\
\hline 7 & 926.27 & 891.97 & 96.3 \\
\hline 7 & 914.84 & 880.53 & 96.25 \\
\hline 7 & 937.71 & 903.4 & 96.34 \\
\hline Rata-rata & 926.27 & 891.97 & 96.3 \\
\hline
\end{tabular}

Hasil analisis persentase perbandingan antara marshall konvensional dengan marshall immersion 
seperti pada tabel 6 memenuhi persyaratan spesifikasi yaitu minimum $90 \%$. Dari hasil rata-rata perhitungan didapatkan nilai Marshall Immersion sebesar $96,30 \%$. Nilai tersebut menunjukkan perkerasan yang menggunakan material ini dalam campuran campuran Stone Matrix Asphalt Halus dapat tahan terhadap suhu dan lamanya terendaman dalam air serta tahan terhadap suhu selama perendaman.

\section{KESIMPULAN}

Batu dari sungai Sa'dan kelurahan Pangli Kecamatan Sesean Kabupaten Toraja Utara dapat dimanfaatkan sebagai bahan untuk campuran Stone Matrix Asphalt (SMA) halus. Kadar aspal yang dapat digunakan pada pencampuran ini, dapat menggunakan kadar aspal antara 6\% sampai dengan $7 \%$ namun untuk mendapatkan campuran yang lebih kedap air dapat menggunakan kadar aspal $7 \%$. Hasil uji marshall immersion dengan menggunakan kadar aspal $7 \%$ adalah $96,30 \%$, hal ini menunjukkan campuran tersebut akan tahan terhadap perendaman selama 24 jam.

\section{DAFTAR PUSTAKA}

[1] S. Sukirman, 2013, Beton Aspal Campuran Panas, Edisi Kedua. Jakarta: Yayasan Obor Indonesia.

[2] R. Rachman, "Pemanfaatan Batu Gunung Bottomale Toraja Utara sebagai Campuran Laston," J. Tek. Sipil Dan Teknol., vol. 6, no. 1, hlm. 20-30, 2020.

[3] G. Rusbintardjo, 2013, Aspal- Bahan Perkerasan Jalan, 1 ed. Semarang, Indonesia: UNISSULA Press.

[4] C. Kamba dan R. Rachman, "Marshall Characteristics Test On Hot Rolled Sheet Base Combine Using Nickel Slag For Half Gap Graded," Int. J. Innov. Sci. Eng. Technol., vol. 5, no. 3, hlm. 14-19, 2018.

[5] A. Kusuma dan R. Rachman, "Study Characteristics of Nickel Slag For Gradient Gap on Mixtured Hot Rolled Sheet Base," Int. J. Innov. Sci. Eng. Technol., vol. 5, no. 3, hlm. 8-13, 2018.

[6] I. M. Batara, R. Mangontan, dan Alpius, 2020, "Pemanfaatan Agregat Sungai Lamasi
Kabupaten Luwu Sebagai Campuran Lapisan Aspal Beton AC-WC," Paulus Civ. Eng. J., vol. 2, no. 3, hlm. 171-179.

[7] K. Marianto, Alpius, dan C. Kamba, "Pengujian Karakteristik Campuran HRS-WC Menggunakan Batu Sungai Makawa Kecamatan Walenrang Utara," Paulus Civ. Eng. J., vol. 2, no. 2, hlm. 128-137, 2020.

[8] G. P. Palimbunga, R. Rachman, dan Alpius, "Penggunaan Agregat Sungai Batu Tiakka' dalam Campuran AC-BC," Paulus Civ. Eng. J., vol. 2, no. 2, hlm. 112-118, 2020.

[9] T. Kurniawan dan Z. Lubis, 2019, "Alternatif Penggunaan Serat Eceng Gondok pada Campuran Stone Matrix Asphalt Gradasi Halus Meningkatkan Stabilitas Campuran Aspal Panas," UkaRsT, vol. 3, no. 1, hlm. 3745.

[10] S. Sunarjono dan R. Samantha, 2012, "Analisis Kekuatan Tarik Material Campuran Sma (Split Mastic Asphalt) Grading 0/11 Menggunakan Sistem Pengujian Indirect Tensile Strength," Surakarta, hlm. 57-64.

[11] D. Sarwono, Pramesti F. Pungky, dan H. L. Kurniawan, 2018 "Analisis Tensile Strength Bending Cantabro dan Permeabilitas pada Split Mastic Asphalt (SMA) dengan Bahan Tambah High Density Polyetylene (HDPE)," E-J. MATRIKS Tek. SIPIL, hlm. 256-262.

[12] A. Sulistia, 2017, "Pengembangan Campuran Split Mastic Asphalt (SMA) Menggunakan Bahan Reclaimed Asphalt Pavement (RAP) dengan Serat Selulosa Alami Dedak Padi," Skripsi, Program Studi Teknik Sipil Fakultas Teknik Universitas Muhammadiyah, Surakarta.

[13] Direkorat Jenderal Bina Marga, Spesifikasi Umum Bina Marga 2018 untuk Pekerjaan Konstruksi Jalan dan Jembatan Divisi 6. Jakarta: Kementerian Pekerjaan Umum dan Perumahan Rakyat, 2018.

[14] R. Rachman, "The Effect of Immersion and Humidification Toward Performance of Hot Rolled Asphalt Mixture," Int. J. Appl. Eng. Res., vol. 15, no. 5, hlm. 503-509, 2020.

[15] S. A. Datu, R. Rachman, dan M. Selintung, "The Effect of Additional Sugar Palm Fibers on the Durability of Mixed Laston AC-WC," dalam The 3rd International Conference on Civil and Environmental Engineering (ICCEE), Bali, Indonesia, 2020, vol. 419, doi: 10.1088/1755-1315/419/1/012063. 